\title{
The Relationship Among Community Based Tourism Application, Community Attitude, Community Empowerment and Community Life Satisfaction
}

\author{
Putu Saroyini Piartrini
}

Udayana University

Corresponding author: royetrini@ unud.ac.id

\begin{abstract}
ARTICLE INFO
Received

20 August 2018

Accepted

20 September 2018

Available online

31 September 2018
\end{abstract}

\begin{abstract}
Tourism involves the movement of individuals from one region to another, which are sometimes of different cultures. The interaction between tourists and local communities in tourist destinations is social interaction. The community does not always react positively to the development of certain destinations or attractions. Public attitudes that are not always beneficial to tourism have various causes, such as the well-being differences that appear so starkly between wealthy tourists and poor local communities and conflict over limited resources such as water, land and cultural resources. This condition needs to be addressed because frequent demonstrations at various tourist attractions in Bali may jeopardize the security and comfort of tourists and affect the image of Bali as an international tourist destination. This study aims to: 1) To evaluate local government policies in community empowerment; 2) To measure perceived community-based tourism implemented in the destination areas 3) To measure thelife satisfaction of the people in tourist destinations; 3)To measure individual attitude toward toursm develoment in Destinations. The results of this study are expected to be useful as input in the formulation of regional tourism policies to realize tourism development goals effectively. This study is different from previous tourism studies because it examines the impact of tourism development from an integral perspective of sustainable tourism and community-based tourism.
\end{abstract}

Keywords: community attitude, community-based tourism, community empowerment, community life satisfaction.

\section{INTRODUCTION}

\section{Background}

Tourism involves the movement of individuals from one region to another, which are sometimes of different cultures. The interaction between tourists and local communities in tourist destinations is social interaction in areas that are different from one another, which then causes social and economic relations between tourists and local communities. The development of tourism is meant to improve the socio-economic conditions of local communities by utilizing their potential in accordance with regional carrying capacity.

Demonstrations held by "For Bali

Tolak Reklamasi (For Bali Refuse Reclamation)" took place in Tanjung Benoa on Friday (15/08/2017), and the closing of access 
to Garuda Wisnu Kencana area (GWK) on Sunday, 24 August 2017 by the local community are indications that the community does not always react positively to the development of destinations or attractions in the region. As for why this can happen, a study is needed to find a productive solution in the long term. The rise of demonstrations in several tourist attractions in Bali can jeopardize the security and comfort of tourists and affect the image of Bali as an international tourist destination. People's attitudes toward tourism activities may be shaped by several causes, including perception of the benefits of tourism activities in the region, the opportunities and intensity of local community involvement in the tourism activities that take place, and the perception of conflict over the limitation of resources needed among local residents, by allocating such resources to accommodation facilities to meet the needs of tourists visiting Bali such as water, land and cultural resources. The research carried out in 2017 is expected to contribute informational findings that may be used as input and consideration in the formulation of policies for the development of tourism activities and the implementation of the concept of sustainable tourism that is integrated with community development in order to improve the quality of life of people in tourism destinations by incorporating community empowerment policies with a conceptual model of research.

The approach to developing sustainable tourism was first introduced by the United Nations Environment and Development Commission Neto (2003) stated that sustainable tourism is the development of tourism activities aimed at meeting today's needs without jeopardizing the ability of natural resources to provide for future generations. In addition to the approach to sustainable tourism development, we can also use alternative approaches, namely community based tourism (CBT). Murphy (2013) states that essentially the development of tourism cannot be separated from the resources and http://ojs.unud.ac.id/index.php/eot uniqueness of local communities, both in the form of physical and non-physical elements (tradition and culture) which are the main driving elements of tourism activities and carried out by communities in their environment, so that tourism should be seen as a community-based activity.

Stakeholders in tourism, especially those in the province of Bali, need to evaluate tourism development efforts and policies that regulate tourism affairs in order to obtain information on whether the implementation of such policies will have the expected impact. Presenza and Cipollina (2010) reported that tourism activities are not only directed at increasing the quality of the economy but need to be directed at improving the quality of social and psychological life which is shown by the comfort, safety and happiness felt by local people living in tourist areas. More specifically, this study aims to: 1) evaluate local government policies in community empowerment which are critical success factors for implementing the concept of community based tourism and sustainable tourism in areas that are tourist destinations based on aspects of economic, psychological, social and political empowerment. The result of this study is evaluative information that integrates economic, social, ecological and psychological aspects of the implementation of Bali's tourism development policies. This study differs from previous tourism studies because it examines the impact of the development of tourism from an integral perspective of sustainable tourism and community-based tourism by including policy variables for community empowerment to measure social impact, in the form of a happiness and welfare index (community wellbeing and happiness).

\section{Research Objectives}

Objectives of the research are:

a. To evaluate correlation between community based tourism level of

e-ISSN: 2407-392X. p-ISSN: 2541-0857 
application and community life satisfaction.

b. To evaluate correlation between community attitude toward tourism and community life satisfaction.

c. To evaluate correlation between community response toward tourism and community life satisfaction.

\section{LITERATURE REVIEW}

\section{Conceptualization and Research Hypothesis}

Simpson (2008) stated that tourism is a social, cultural and economic phenomenon that requires the movement of people to countries and places for personal or business purposes. Tourism is influenced by the potential for tourism in certain places, being extraordinary in nature, culture, art and other resources in a particular place; in a country that functions as a tourist attraction, it may lie in natural beauty, because of the human instinct to appreciate aspects of nature such as landscapes, lakes, mountains or hills, rivers, rocks, waterfalls, caves, monoliths, wildlife, among others; and the limitless potential for man-made tourism which includes extraordinary art and architectural works, museum objects, archeology and site culture. Every ciizen has the right to be involved in any development activities thar targeted at meeting community needs. Self help community activities need to be facilitated by stakeholders including the youths who are legitimately the future custodian of the welfare of their community and the greatest investment that can be utilized to mobilize local material resources for the community as well as the country's development (Mbagwu et al., 2016).

The approach to sustainable tourism development was first introduced by the United Nations Environment and Development Commission. The development of sustainable tourism aims to meet today's needs without jeopardizing the needs of future generations. Sustainable development must take into consideration the use of the environment and the preservation of the environment so that the quality of the environment be maintained. The neglect of environmental preservation will cause an environment's carrying capacity to decrease, or even disappear. Sustainable development involves achieving social justice from generation to generation. Judging from other meanings, sustainable development as national development preserves the functions and capabilities of ecosystems. Sustainable development must involve actions that can preserve the natural environment (Hunter, 1997). Sustainable development has the following characteristics: 1) Providing possibilities for survival by preserving the functions and capabilities of the ecosystem that supports it, in both directly and indirect ways; 2) Utilizing natural resources by utilizing technologies that do not damage the environment; 3) Providing opportunities for other sectors and activities to develop together in each region, both in the same time period and in different periods of time on an ongoing basis; 4) Increase and preserve the ability and function of ecosystems to supply, protect, and support natural resources for life sustainably; 5) Utilize procedures that take into account the sustainability of the functions and capabilities of the ecosystem to support life, both now and in the future.

Meaningful tourism evaluation system is based on on multi perspectives such as financial yield, economic yield and environmenal yield, social yield and cultural yield. Economic yield is related to tha gain that tourism brings to the economy, such as employment, development of infrastructure and economy diversification (NorthCote, Jeremy \& Macbetth, Jim, 20015). Five types of environmental indicators proposed for the detailed indicators are such as: Fragility of ecosystem and biodiversity; waste disposal; water consumption; intensity of land use and physical impact; protection of the atmosphere, 
noise level and visual impact (Lim and McAleer, 2005). World travel \&Tourism Council reported that in 2017, the direct contribution of Travel and tourism to GDP was USD 2,.306,0 bn, accounted for $10.2 \%$ of total GDP. Tourism industry contributed 138.086.000 jobs in 2017. In Indonesia Tourism direct contribution in 2017 was IDR 405,975.0bn. GDP total contribution was $4,3 \%$. The tourism industry directly supported 2,517,000 jobs meanwhile total employment was 9,080,000 jobs. Liu, Liu and Towsley (2003) criticizes the application of sustainable tourism concepts that look at macro issues.

\section{Sustainable Community Based Tourism and Community Life Satisfaction}

\section{The Community Based Tourism} Development Approach provides additional options in managing tourism activities. In the tourism sciences, it is referred to as the strategy of community-based tourism (CBT). Community-based tourism construction in principle is one of the alternatives in the approach to conventional tourism-oriented growth models that have attracted much criticism because they have been seen to marginalize and ignore the rights of local communities from tourism activities in the destination region. As already stated by Murphy (2013) that essentially tourism development cannot be separated from the resources and uniqueness of local communities, both physical elements and nonphysical elements in the form of tradition and culture, which are themselves the main driving elements of tourism activities. Thus the Community must be the basis for developing tourism activities. Blackstock (2005) provides an idea of community-based tourism as follows: 1) A form of tourism governance that provides opportunities for local communities to control and be actively involved in the management and development of existing tourism; 2) The form of tourism management that can provide opportunities for people directly involved in tourism businesses so that they can also benefit from existing tourism; 3) Forms of tourism that demand systematic and democratic empowerment and fair distribution of benefits to disadvantaged communities in destinations (Goodwin and Santilli, 2009).

According to Hudson and Timothy (1999), community-based tourism is an understanding related to the certainty of benefits obtained by the community and the existence of mentoring planning efforts that defend local communities and other groups who have an interest in local tourism, and governance tourism which provides greater control space to actualize the welfare of local people. Community-based tourism is closely bound to the certainty of active participation of local communities in the existing tourism development. Community participation in tourism consists of two perspectives, namely community participation in the decisionmaking process and participation in the distribution of benefits received by the community from tourism development. Empirical work conducted by Ghosh (2011) revealed that there was no long-term equilibrium relationship between international tourist arrivals and economic activity in India. The study also fails established any short-run relationship between international tourist arrivals and economic growth. To attract more visitors, India still needs to upgrade basic tourism infrastructures, such as airports, railways, roads, waterways along with various amenities, such as uninterrupted power and water supply, cleaning the air, solid waste management. Future development of tourism, therefore, involves the integrated development of infrastructure and amenities along with all the tourism facilities in a balanced and environmentally responsible manner. Community development has an important role to play in local tourism communities, such as Port Douglas. A CBT that is informed by a community development ethos could provide an important tool for residents who wish to ensure that tourism enhances rather than 
destroys their communities (Blackstock, 2005).

Lee, T.H.,( 2013) reported that there was strusctural relationship among perceived benefits, perceived cost, community attachment and community involvement, as well as support for sustainable tourism development. Perceived benefits of Sustainable tourism development directly influenced support for sustainable development. On the other hand, opment. Community attachment also positively affected the perceived benefits of sustainable tourism development. Community involvement also effected perceived benefits of sustainable tourism development and therefor positively support sustainable tourism development. At the same model also reported that community involvement negatively effected the perceived cost and then insignificantly influenced community support for sustainable tourism deelopment. Juvan, E., \& Dolnicar, S. (2014) also stated that there are gap between attitude and behavior in sustainable tourism that influenced community life satisfaction. The relationship between Application of community based tourism and community life satisfaction is as follow:

\section{The First Hypothesis $\left(\mathrm{H}_{1}\right)$}

$\mathrm{H}_{0}$ : There is no positive correlation between Community based tourism level of application and community life satisfaction.

$\mathrm{H}_{1}$ : There is positive correlation between Community based tourism level of application and community life satisfaction.

\section{Community Attitude toward Tourism and Community Life Satisfaction.}

Positive attitudes were connected with the belief and percieved performance that tourism creates community development, opportunities for earning income, improved http://ojs.unud.ac.id/index.php/eot agricultural markets, and a chance at good fortune (Lepp, 2007). Community attitude toward tourism are relfections of the impact of tourism activity on community aspects of live namely: Economic and employment impacts, Socio cultural impacts, Environmental impacts, Accessibility and quality of life impacs and public funding and future development options (Lepp, 2007). Irandu (2004) deployed the Irridex model develop by Doxey (1975) to describe linear changes in the attitude of local people towards tourists. A positive initial attitude gradually becomes increasingly negative as the number of tourists visiting the Destination increases. The stages of people's changing attitudes towards tourists visiting the destination are described as the following stages:

a. Euphoria stage. At this stage tourist arrivals are well received, with a million positive hopes. This occurs in the initial phases of tourism development in a tourist destination, and in general these tourist destinations have not established development planning.

b. Stage of Apathy. At this stage the community accepts tourists as something ordinary and the relationship between people and tourists is dominated by commercial relations. Planning carried out in tourist destinations in this phase generally only emphasizes the marketing aspect.

c. Annoyance Stage. At this stage, saturation is almost achieved and people begin to feel disturbed by the presence of tourists. Planning generally seeks to improve infrastructure and facilities, but there is no attempt to limit growth.

d. Stage of Antagonism. At this stage the public has openly expressed displeasure or negative reactions and has come to view tourists as a source of trouble in their social life. It is usually only in this stage that the importance of integrated overall planning is realized. 
Tourism Development has some impacts on community.The economic contribution of tourism activities in areas that become tourist destinations can be hindered by the intensity and quantity of available economic activity facilities in the destination region and their impact on the quality of economic life of the people living in the region. The economic contribution of tourism is indicated by the people's purchasing power, which results from the income obtained through the expenditure of visiting tourists (Ghosh, 2011). International tourists spend dollars in the host countries visited during their trip. Tourist spending on tourist travel has increased. Petri and Plummer (2016) already predicted the value of the economic effects of the Trans-Pacific. In other part The WTO (2016) Reported that tourism activities contributed greatly to foreign exchange earnings of several developing and developed countries for community development by providing for local people in the form of local labor, basic facilities, educational opportunities and infrastructure facilities in order to improve their welfare. Tourism is an important infrastructural component in the economic development of countries in the world and is mentioned as an invisible export, which can trigger economic and social transformation. Identification of the positive and negative aspects of tourism as perceived by residents and the influence of variables on resident response are useful in setting up programs to minimize friction between tourists and residents, and in formulating plans to gain resident support of tourist ventures (Belisle, F.J. and Hoy, D.R., 1980). It is hypothesized that the perception of tourist impact varies with the distance a person lives from the tourist zone and with the resident's socio-economic.

Tourism's economic contribution is now large and cannot be underestimated in many countries because of faster growth from other economic sectors (Mbagwu et al., 2016). A number of evidence were presented by http://ojs.unud.ac.id/index.php/eot
Rutty, M., Gössling, S., Scott, D. and Hall, C., (2015) that there is relationship between visitors spending and economy development in Eastern Afirica, Midle africa, western Africa, Northen Africa, Southern Africa, Eastern Asia, werstern Asia, Southern Asia, Southeast Asia, Central America, South America, Carribean and Oceania.Tourism acts as a catalyst for the growth of trade and industry and an increase in self-employment opportunities such as setting up a restaurant, kiosk and cafe that can facilitate rapid livelihood of more than a formal job (Dwyer, Forsyth and Spurr, 2003). In the era of globalization, the economic and social contribution of tourism to community development cannot be ignored by the government, society and individuals. Peters (1969) and Stabler, M.J., Papatheodorou, A. and Sinclair, M.T., (2009) stated that no country in the world ignores the importance of tourism for economic, social and cultural development. Various nations and groups of countries have become increasingly aware of the socio-economic benefits generated from tourism. Gössling (2002) states that tourism became a popular global leisure activity in the form of a unique smokeless industry, a classless educational institution, integration without law, and diplomacy without formality.

Social interaction between tourists and local communities nurtures a relationship of mutual respect, tolerance, understanding, awareness, family ties, learning, respect and liking. To satisfay visitors expectations in host country, at the same time the citizens of the host country or state can be enriched by information about the outside world, can also enjoy facilities such as schools, libraries, health institutions, and internet facilities provided by the tourism industry (Andereck $e t$ $a l ., 2012$ ). Tourism has been recognized as a basic human activity and is expected to contribute to investment in the arts and culture, and the formation of a new international economic order that will help to eliminate the economic gap between 
development and progress, especially in developing countries (Mbagwu et al., 2016). In reality the benefits of tourism activities in a tourist destination not only produce a positive impact on the socio-economic life of the community but also unwittingly foster negative impacts that are not in line with the prevailing norms in society. It cannot be denied that the growth of positive impacts and benefits of tourism activities refract negative social impacts that cannot be ignored, which this study attempts to explore. It is worth studying whether tourism activities are seen as having an impact on indigenous peoples' identities and community values, cultural clashes, increased crime, increased living costs, demand for resources and disturbing ethical problems in increasing sex tourism or exploitation of child labor in host communities. Potential impacts of natural /biotic environmental tourism activities that should be anticipated include: 1) Declining natural resources in the form of reduced water resources, land degradation, local resources, declining wildlife or wild population, and changes in wildlife behavior; 2) Pollution: Air and sound pollution, water and soil pollution, waste, liquid waste, aesthetic pollution; 3) Physical impacts of the area: Excessive and incompatible development with the environment, land clearing, marina construction, liquid waste, aesthetic pollution, and breaking the regional carrying capacity (Gössling, 2002). Tourist guests who visit the destination can be asked to provide an assessment of the quality of the destination's natural environment. Hughey, Kerr and Cullen (2010) stated The New Zealand Environmental Indicator Set for Tourism in 2010, dividing indicators of environmental physical impacts into: 1) Waste / Waste, Environmental impact shown by environmental cleanliness. Solid waste performance indicators are measured based on the level of comfort of tourists with the cleanliness of the environment visited and the availability of hygiene facilities and means of recycling waste; 2) Water, Environmental impacts are assessed through the quality of water available in the visited destination. The available water quality can be specified in more detail based on continuity, quality and quantity; 3) Transportation, transportation performance can be measured by the average mileage per guest traveler, the average value spent on the types of modes of transportation by tourists; 4) Energy, reported the impact of tourism on energy is measured based on the average energy consumed by the tourism sector especially the transportation and accommodation sub-sectors in both the total value and per guest visitor during a certain period; Greenhouse Gases. The impact of tourism on the greenhouse gas produced by the tourism sector, in the transportation and accommodation sectors specifically: in total, per visitor (international) and per trip (domestic); Environmental Accreditation. The impact of tourism activities on the environment can be assessed from the accreditation of tourism destination environments indicated by Gold, Silver or bronze accreditation qualifications; Landscapes. The impact of tourism activities on the physical environment is evaluated through a resident satisfaction index of the beauty of the natural environment and views of tourism destinations; Biosecurity. The impact of tourism is also evaluated based on the level of health of tourists that culminates and is measured through indicators of the number of seizures per 1000 arrivals either by air, sea or land ;Biodiversity (Sunlu, 2003). The impact of tourism on environmental conservation is measured through the area that is legally protected by legislation and has permanent legal force. Miller, G.(2001) also indicated that sustainability can be measured by employment level, policy relevance, financial leakages, tourist satisfaction, host community satisfaction and environmental impact. Teye, Sirakaya and Sönmez (2002) reported that community attitude toward tourism is not necessary positive. Satisfaction with neighborhood conditions was also found to be a determinant of perceived benefits and overall community satisfaction 
(Nunkoo and Ramkissoon, 2011). Kim, Uysal and Sirgy (2013) showed that the relationship between the economic and social impact of tourism and the satisfaction with its correspondent life domains (material wellbeing and community well-being) initially decreased in the growth stage of tourism development and peaked in maturity stage of tourism development. However, when a community enters the decline stage of tourism development, the strength of the relationship between the economic and social impact of tourism and the satisfaction with correspondent life domains decreases. Relationship between community attitude or response toward tourists and community life satisfaction is formulated as follow:

\section{The Second Hypothesis $\left(\mathrm{H}_{2}\right)$}

$\mathrm{H}_{0}$ : There is no positive correlation between community attitude toward tourism and community life satisfaction.

$\mathrm{H}_{2}$ : There is positive correlation between community attitude toward tourism and community life satisfaction.

\section{Community Empowerment}

Castañeda (2012) refering to the UNWTO Global Ethics for tourism adopted by the UN General Assembly in 1990 ten basic principles were launched that serve as guidelines for tourism actors to ensure that tourism activities are carried out with the aim of maximizing social benefit and environmental conservation. The integration of the Global Sustainable Tourism Council (GSTC) with the Sustainable Tourism Stewardship Council (STSC) in September 2009 that oversees the WTOUN, travel companies, hotels and tourism boards in various countries establish the main pillars of tourism sustainability, namely: 1) realizing sustainable destination management; 2) maximizing the economic benefits of the host community and minimizing negative impacts; 3) maximizing benefits for the community, guest tourists, cultural conservation and negative impact minimization; 4) minimizing negative impacts on the environment. Besides there are a number of potential opportunities, there are also some limits for community to involve in tourism developments specifically: Centralization of public administration of Tourism, Lack of co-ordination, Lack of Information, Attitudes of professionals, Lack of expertise, Elite domination, Lack of appropriate legal system Lack of trained human resources, Relatively high cost of community participation, Lack of xnancial resources, Limited capacity of poor people, ApathyandLowLevel of awarenessinthe local community (Tosun, 2000). In order to actualize the sustainability of tourism development based on the 4 main pillars, the key to success is community empowerment (Cole, 2006), which includes: 1) Economic empowerment; 2) Psychological empowerment; 3) Social empowerment and 4) Political empowerment.

Empowerment in the economic field is an effort made to improve the economic capacity of the community in the area of tourism destinations and provide the widest business opportunities through ownership of micro, small and medium enterprises (Harrison and Schipani, 2007). Community capability is built and enhanced so that it can become part of the local, national and regional production value chains (Butler, 1999). Providing access to funding sources for the wider community, connecting MSMEs to large business networks, capacity building through training programs, equitable allocation of resources among community groups. Empowerment in the social aspects of community life includes efforts to provide maximum opportunities for participation and provide opportunities for collaboration, increase cohesiveness of community groups, increase the intensity and quality of interaction among stakeholders, actualize quality communal life, conservation of tourism resources, gender mainstreaming in activities tourism. stated that empowerment of psychological aspects includes efforts to increase community involvement and commitment to the conservation of tourism resources both independently and collaboratively; provide education to the community in order to foster interaction 
between the host community and qualified guest tourists, actualize the host community satisfaction and the satisfaction of the guests who visit the destination and maintain and protect local identity. Preservation of tradition is extremely important in terms of maintaining a group's sense of self-esteem and well-being (Mansperger, 1995). Political empowerment can be done through increasing community participation in tourism-related decision making in their respective regions, support of local governments and the central government in tourism development and enhancing the vision and commitment of community leaders. Local community empowerment correlated with community optimistic about the future, faith in their abilities, self-reliant and pride in traditions and culture (Scheyvens, R., 1999). Kang et al. (2003) reported that body satisfaction positively correlated with body esteem.

\section{The Third Hypothesis $\left(\mathrm{H}_{3}\right)$}

The relationship between community based application and community life satisfaction is hyphotezised as follow:

$\mathrm{H}_{0}$ : There is no positive correlation between community response toward tourism and community life satisfaction.

$\mathrm{H}_{3}$ : There is positive correlation between community response toward tourism and community life satisfaction

\section{Research Conceptual Framework.}

Present study proposes conceptual model regarding relationship among community based tourism, community empowerment , community attitude and community life satisfaction. Conceptual model and testing hyphotesis is presented as follow.

http://ojs.unud.ac.id/index.php/eot

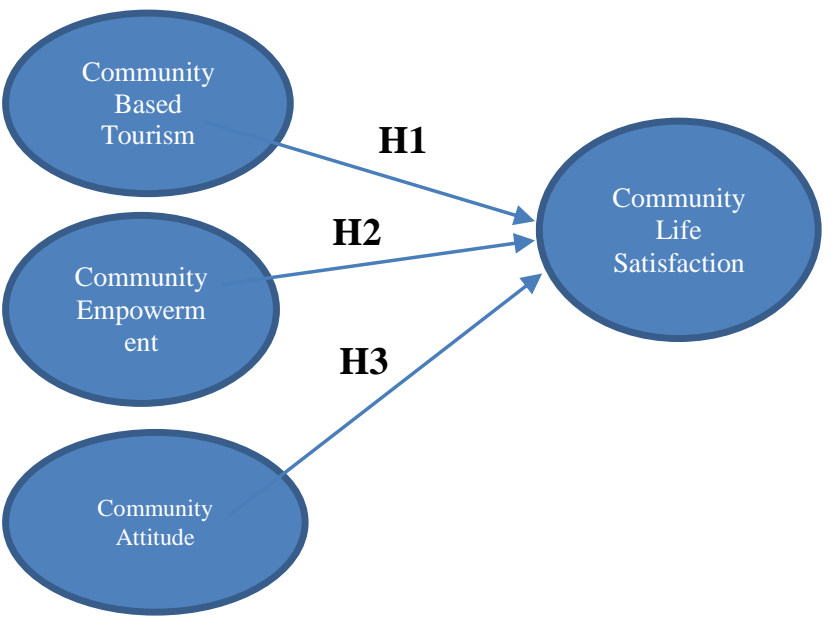

Figure 1. Proposed Conceptual Model

\section{RESEARCH METHOD}

The results of the interview are to be used as a basis for evaluating and assessing the implementation of sustainable tourism development and community-based tourism confirmation to tourists through a structured questionnaire instrument to get an overview of their perceptions and life satisfaction index related to the development of tourism activities in their area of residence.

Formulation of Regression equation models that have aspects of the application of community-based tourism concepts, community attitude, community empowerment were regressed to indicators of life satisfaction. The formulation of the model will be seen from the perceptions of individuals who live in the region of South Kuta and Kediri destinations that are close to the Pecatu and Tanah Lot destinations. Questions in a structured questionnaire that was submitted to the people living in the sample destination.

Research data collection was carried out by exploratory initial studies and through surveys in South Kuta Sub-district and Kediri Sub-district. Beginning with interviews with community leaders and tourism practitioners to identify destination management policies which were then followed by a survey to measure life satisfaction indexes, perceptions 
of the implementation of community-based tourism concepts, and perceptions of community empowerment and community response to tourism activities in its environment.

The research population was composed both of community members who have a direct relationship with tourism as well as those who have no direct relationship with tourism activities in the South Kuta Sub district and the Kediri sub district, Tabanan regency. Subject on the research are individuals living in the destination areas. The second phase of the study was a survey involving 300 individuals in various primary data sources to measure the life satisfaction index, the perception of the implementation of community-based tourism concepts and the perception of community empowerment as a moderator variable and the community's response to tourism activities in their environment. Secondary data sources are the Central Statistics Bureau, the Regional Archive Agency and Village monographs as well as relevant Local Government publications. Data collected from secondary sources includes levels of per capita income, types of legislation related to tourism and policies that are relevant to the welfare of the community. Quantitative research data includes population, average life expectancy and average length of education, while qualitative data includes employment and tourist attractions on offer, among others. The data collection methods used in this study were structured interviews using a list of statements and a list of questions that were completed by individuals using convenience /non probability sampling techniques at the research location. Data were measured by followong instruments such as:

1. Community Based Tourism were measured data by SUS-TAS Scale, developed by Sirakaya, Ercan Turk (2005), that is consist of 44 item. It measures 7 dimensions of Community Based and Sustainable tourism such as :

http://ojs.unud.ac.id/index.php/eot perceived social cost; Environmental sustainability; Longterm planning; perceived economic benefit; community center economy; Ensuring Visitor satisfaction; Maximization community participation. Validity dan reliability of instrument is acceptable with explained varians toral $67 \%$ and Alpha Cronbach 0,87 .

2. Sustainably Community Based Tourism was measured by based on dimensions ; local employment, local partnershippeningkatan standar hidup dan kesejahteraan; peningkatan sumber pendapatan, peningkatan kerja sama pelaku bsnis dengan masyarakat in business development, skill development for community, local management, culture convation, and natural resources conservation. Based on values of total variance explained $65,5 \%$ and Alpha $=0,59$, the instrument is valid and reliable.

3. Life satisfaction data were measured by MLSS scale which is consist of dari 40items. Data were measured on 4 intervals: (never on $=1)$; $($ sometimes = $2)$; (often $=3$ ); and (almost always $=4$ ). The higher the score, the higher the life satisfaction level. The instrument is valid and reliable with total variance explained 61,8\% Alpha 0,60.

4. Data host population's response toward tourism were measured by the following set of questions ( Zaidan, E., \& Kovacs, J. F. ,2017) such as; Do you believe that development in Bali is geared more to the needs of tourists as opposed to locals? Are you satisfied with the vision outlined in Bali Tourism Vision to host 10 million tourists? Do you believe that Bali would not be what it is today without tourism development? Do you believe that tourism is essential for continued prosperity in Bali ?

e-ISSN: 2407-392X. p-ISSN: 2541-0857 


\section{RESULTS AND DISCUSSION}

Data accummulation involved 300 respondents living in the south Kuta area and Tanah Lot area. Because of incomplete data provided by some respondent there just 280 data set available to analyze (Respon rate 93,3\%). Descriptive analysis indicated average score, minimum score, maximum score and number of data as those presented on Table 1.

Table 1. Description Variables Score

\begin{tabular}{lcccc}
\hline & N & Minimum & Maximum & Mean \\
\hline CBT & 280 & 53,00 & 128,00 & 98,35 \\
Tourism & 280 & 17,00 & 33,00 & 24,8 \\
Impact & & & & \\
Comm_Sat & 280 & 53 & 132 & 96 \\
Comm_resp & 280 & 36 & 49 & 38 \\
\hline
\end{tabular}

The multiple linear regressions regarding the modulation of Perception of Impelementation of Community based Tourism, community attitude , community empowerment and community Life Satiscation is formulated as follow :

$\mathrm{Y}_{\text {Life_Sat }}=45,17+0,311$ CBT $+0,217$

Tourism impact $+0,381$ Comm resp. + e.

Contribution of Variation of three independent variables; Impelementation of Community based Tourism, community attitude and community empowerment on variation of one dependent variable, community Life Satiscation is $38.9 \%$; with confidence interval $95 \%$ or a $=5$. Validity of Regression model requires verification to make sure that the model does not violate fundamental assumptions through : normality test. Multicoliniarity test and heteroskedasicity test. Based on Statistic Kolmogorov-Smirnov the data are distributed normaly with Asymp.Sig $>a=0.05$. Multicolinearity showed the score of tolerance and variance inflation factor $(\mathrm{VIF})=0.905$ and $\mathrm{VIF}=1.105$, no

http://ojs.unud.ac.id/index.php/eot multicoliniarity showed. Heteroscedascity test done by Glejser and Park Method, if there was a significant probability the scored wwould be higher than confidence value then the result indicated no heterocedacity produce.

\section{Hypotheses Testing}

The hypotheses showed the perception toward CBT and Tourism Impact give significant impact on life satisfaction through $\mathrm{F}$ test. Resulting in $\mathrm{F}_{\text {hitung }}(1,178)=19,344$. on significancy $95 \%$ or no error probability more than $5 \%$, perception on CBT and social impact and affect on life satisfaction show $\mathrm{R}^{2}=38,9 \%$. Partially CBT variables correlated positively with life satisfaction variable $($ beta $=0,311 ; \mathrm{t}=4,364 ; \mathrm{p}=0,05$ meanwhile tourism impact correlated with life satisfaction ( beta $=0,217: \mathrm{t}=3,042 ; \mathrm{p}<$ $0,05)$, as well as community attitude /respons ( beta $=0,381 ; \mathrm{t}=2.001 ; \mathrm{p}=0,052$ ).

\section{CONCLUSION}

The implementation of communitybased tourism concept, community empowerment and community attitude significantly correlated with community life satisfaction. Host community is foundation of tourism development. Their attitude, opinio and expectation need to take into account when developing tourism destination. Negative attitude held by community toward tourism potentially induce boycotting at the site. Government is recommended to embrace host community expectation as well as private sector that will bring capital to invest at the destination to develop it.

The core foundations of tourism development are government, private sectors and citizen/host community. Central government and regional government responsibilities as a regulator is establishing rules, policies and standards regarding natural resources utilization and tourism resources developmen. Community expectation and 
capacity must be accomodated. Different interest of stakeholders need to be managed properly and proportinally to sustain the activities in the long run. It is highly recommended to involve host community in decision making process to build ownership in developing tourism activity. The citizens are given opportunity to develop and provide services and tourism product based on their capacity and competency. The development of the understanding on tourism activity in the community need to be revisited, emphasizing on individual and community empowerment to minimize negative impact on tourist activity. Information regarding tourism activity should be available and should be easy to access by the community member. Extreme attitude towards tourist beause of missperception in certain areas can be the cause of inconvenience.

\section{RECOMMENDATION}

The regulations in developing the tourism destinations need to be more participatif and open more space for the host community to take part in tourism development decision process. Sustainable tourism requires both the sustainable growth of tourism's contribution to the economy and society and the sustainable use of resources and environment (Liu, Liu and Towsley, 2003). Present study employs additive conceptual model to test the impacts of community based tourism, community attitude and community empowerment on community life satisfaction. In the future study it is recommended to redesign contingency conceptual model on which community empowerment place as moderating variable between private based torism development and community attitude as well as community life satisfaction to verify whether community empowerment plays moderating role to lessen community negative attitude toward tourism activityand life satisfaction with larger sample size accumulating from different level destination planing quality. It is advisable to http://ojs.unud.ac.id/index.php/eot use renewable energy sources (RES) that will have a large potential to contribute to the sustainable development of Environment friendly tourism industry in Bali and at the same time provides the community with a wide variety of socioeconomic benefits, including diversification of energy supply, enhanced regional and rural development opportunities, creation of a domestic industry and employment opportunities (Del Rio, P. and Burguillo, M., 2009).

\section{REFERENCES}

Andereck, K. et al. (2012) 'Experience expectations of prospective volunteer tourists', Journal of Travel Research. Sage Publications Sage CA: Los Angeles, CA, 51(2), pp. 130-141.

Blackstock, K. (2005) 'A critical look at community based tourism', Community development journal. Oxford University Press, 40(1), pp. 39-49.

Butler, R. W. (1999) 'Sustainable tourism: A state-of-the-art review', Tourism geographies. Taylor \& Francis, 1(1), pp. $7-25$.

Castañeda, Q. (2012) 'The neoliberal imperative of tourism: Rights and legitimization in the Unwto global code of ethics for tourism', Practicing Anthropology. JSTOR, 34(3), pp. 4751.

Cole, S. (2006) 'Information and empowerment: The keys to achieving sustainable tourism', Journal of sustainable tourism. Taylor \& Francis, 14(6), pp. 629-644.

Dwyer, L., Forsyth, P. and Spurr, R. (2003) 'Inter-industry effects of tourism growth: implications for destination managers', Tourism Economics. SAGE Publications Sage UK: London, England, 9(2), pp. 117-132. 
Ghosh, S. (2011) 'Examining tourism-led growth hypothesis for India', International Journal of Indian Culture and Business Management. Inderscience Publishers, 4(3), pp. 347-355.

Goodwin, H. and Santilli, R. (2009) 'Community-based tourism: A success', ICRT Occasional paper. International Centre for Responsible Tourism, Leeds Metropolitan University, 11(1), p. 37.

Gössling, S. (2002) 'Global Environmental Consequences of Tourism', Global environmental change, 12(4), pp. 283302.

Harrison, D. and Schipani, S. (2007) 'Lao tourism and poverty alleviation: Community-based tourism and the private sector', Current issues in tourism. Taylor \& Francis, 10(2-3), pp. 194-230.

Hughey, K. F. D., Kerr, G. N. and Cullen, R. (2010) Public perceptions of New Zealand's environment: 2010. EOS Ecology.

Hunter, C. (1997) 'Sustainable tourism as an adaptive paradigm', Annals of tourism research. Elsevier, 24(4), pp. 850-867.

Irandu, E. M. (2004) 'The role of tourism in the conservation of cultural heritage in Kenya', Asia Pacific journal of tourism research. Taylor \& Francis, 9(2), pp. 133-150.

Kang, S.-M. et al. (2003) 'Culture-specific patterns in the prediction of life satisfaction: Roles of emotion, relationship quality, and self-esteem', Personality and Social Psychology Bulletin. Sage Publications, 29(12), pp. 1596-1608.

Kim, K., Uysal, M. and Sirgy, M. J. (2013) 'How does tourism in a community impact the quality of life of community residents?', Tourism Management. Elsevier, 36, pp. 527-540.
Lepp, A. (2007) 'Residents' attitudes towards tourism in Bigodi village, Uganda', Tourism management. Elsevier, 28(3), pp. 876-885.

Lim, C. and McAleer, M. (2005) 'Ecologically sustainable tourism management', Environmental Modelling \& Software. Elsevier, 20(11), pp. 1431-1438.

Liu, B., Liu, Z. and Towsley, D. (2003) 'On the capacity of hybrid wireless networks', in INFOCOM 2003. TwentySecond Annual Joint Conference of the IEEE Computer and Communications. IEEE Societies. IEEE, pp. 1543-1552.

Mansperger, M. C. (1995) 'Tourism and cultural change in small-scale societies', Human Organization. JSTOR, pp. 8794.

Mbagwu, F. et al. (2016) 'Youths Involvement in Self-Help Community Development Projects (SHCDPs) in Nsukka, Enugu State, Nigeria'. Canadian Center of Science and Education.

Murphy, P. E. (2013) Tourism: A community approach (RLE Tourism). Routledge.

Neto, F. (2003) 'A new approach to sustainable tourism development: Moving beyond environmental protection', in Natural resources forum. Wiley Online Library, pp. 212-222.

Nunkoo, R. and Ramkissoon, H. (2011) 'Developing a community support model for tourism', Annals of Tourism Research. Elsevier, 38(3), pp. 964-988.

Peters, M. (1969) International tourism: The economics and development of the international tourist trade. Hutchinson London.

Petri, P. and Plummer, M. (2016) 'The economic effects of the Trans-Pacific Partnership: New estimates'. 
Presenza, A. and Cipollina, M. (2010) 'Analysing tourism stakeholders networks', Tourism Review. Emerald Group Publishing Limited, 65(4), pp. 17-30.

Simpson, M. C. (2008) 'Community benefit tourism initiatives-A conceptual oxymoron?', Tourism management. Elsevier, 29(1), pp. 1-18.

Sunlu, U. (2003) 'Environmental impacts of tourism', in Conference on the Relationships between Global Trades and Local Resources in the Mediterranean Region, pp. 263-270.

Teye, V., Sirakaya, E. and Sönmez, S. F. (2002) 'Residents' Attitudes Toward Tourism Development', Annals of tourism research, 29(3), pp. 668-688.

Tosun, C. (2000) 'Limits to community participation in the tourism development process in developing countries', Tourism management. Elsevier, 21(6), pp. 613-633. 